\title{
MENINGKATKAN MUTU PENDIDIKAN MELALUI ADMINISTRASI DAN SUPERVISI SARANA DAN PRASARANA
}

Oleh :

\author{
ELSA RUDATUL ILMI
}

elsarudatulilmi@gmail.com

\begin{abstract}
Abstrak
Keberhasilan program pendidikan sangat dipengaruhi oleh banyak faktor, salah satu diantaranya adalah tersedianya sarana dan prasarana pendidikan yang memadai disertai pemanfaatan dan pengelolaan secara optimal.Untuk itu perlu dilakukan peningkatan dalam penggunaan dan pengelolaan sarana dan prasarana, agar tujuan yang diharapkan dapat tercapai. Dewasa ini masih sering ditemukan sarana dan prasarana pendidikan yang dimiliki oleh sekolah tidak optimal penggunaannya dan bahkan tidak dapat lagi digunakan sesuai dengan fungsinya. Hal itu disebabka oleh kurangnya kepedulian terhadap sarana dan prasarana yang dimiliki serta tidak adanya pengelolaan yang memadai.
\end{abstract}

Kata kunci: pengelolaan sarana dan prasarana secara optimal

\section{LATAR BELAKANG}

Menurut (Sabandi, 2013) Perkembangan ilmu pengetahuan, teknologidan sosial ekonomi masyarakat dapat lebih memperluas variasi pendekatan peningkatan kapasitas guru. Secara umum dikenal,kapasitas guru. Secara umum dikenal, supervisi dilakukan oleh supervisor dengan melakukan oleh supervisor dengan melakukan kunjungan kelas. Supervisor memeriksa persiapan kunjungan kelas. Supervisor memeriksa persiapan guru mengajar guru mengajar dan mengomentari persiapan dan mengomentari persiapan mengajar yang dibuat oleh guru. Selanjutnya,mengajar yang dibuat oleh guru. Selanjut mengamati mengajar dan mencatat segala sesuatu mengamati mengajar dan mencatat segala sesuatu berkenaan dengan pelaksanaan pembelajaran yang berkenaan dengan pelaksanaan pembelajaran yang dilakukan oleh guru. Hasil pengamatan tersebut dilakukan oleh guru. Hasil pengamatan tersebut dibicarakan dengan guru; supervisor memberikan dibicarakan dengan guru; supervisor memberikan komentar kepada guru tentang hal-hal yang perlu hal yang perlu ditingkatkan. Pendekatan supervisi yang demikian pendekatan supervisi yang demikian tidak selalu dilakukan secara utuh. Sering supervisi tidak selalu dilakukan secara utuh. Sering supervisi dilakukan hanya sampai pada tahap memeriksa dilakukan hanya sampai pada tahap memeriksa rencana pembelajaran atau mengamati pelaksanaan rencana pembelajaran atau mengamati pelaksanaan pembelajaran guru di kelas.

Untuk meningkatkan kualitas kinerja guru disekolah, salah satunya adalah dengan meningkatkan kompetensi supervisi oleh sarana prasarana sekolah. Meningkatkan kinerja guru baik dari segi pengetahuan maupun ketrampilan,dan juga dalam pembelajaran perlu dikembangkan situasi belajar dan mengajar yang lebih baik dalam usaha mencapai tujuan belajar yang ditentukan. Peranan sarana dan prasarana sekolah dalam supervisi pengajaran sangat menentukan kualitas pembelajaran.

Agar peserta didik mendapatkan pembelajaran yang optimal maka perlu diperhatikan menyediakan fasilitas sekolah yang memungkinkan peserta didik untuk belajar diruang belajar yang 
memadai,menyediakan media pembelajaran serta kelengkapan laboratorium dan perpustakaan yang memungkinkan peserta didik untuk belajar secara optimal.

Oleh karea itu perlu untuk meningkatkan kinerja guru yang didukung oleh sarana dan prasarana yang memadai dari sekolah namun dalam praktiknya di lapangan selama ini sarana dan prasarana yang dibutuhkan oleh guru masih jauh dari harapan. Kenyataannya, pelaksanaan supervisi oleh sarana prasarana sekolah,masih terfokus pada pengawasan administrasi. Pada umumnya sarana dan prasarana sekolah akan melakukan supervisi pengajaran (pembelajaran) pada guru melalui kunjungan kelas.

Berdasarkan latar belakang tersebut dirumuskan masalah bagaimana cara meningkatkan mutu pendidikan melalui adsarana dan prasarana?. Tujuan pada pembahasan ini adalah untuk mengetahui apa saja yang dapat dilakukan untuk mengoptimalkan sarana dan prasarana dalam pendidikan.

\section{PEMBAHASAN}

Menurut (Ismanto, 2016) Guru memiliki peran strategis untuk mewujudkan visi dan tujuan pendidikan nasional melalui proses pembelajaran. Perkembangan teknologi informasi tidak dapat menggeser guru dalam pengelolaan dan kepemimpinan proses pembelajaran. Sebagai pengelola pembelajaran, guru melakukan perencanaan, pelaksanaan, pengawasan dan evaluasi pembelajaran. Sebagai pemimpin, guru akan memotivasi, mengarahkan dan menciptakan pengaruh agar siswa berperilaku positif. Teknologi informasi diberdayakan untuk pemecahan kesulitan belajar dan meningkatkan akselerasi dalam pengembangan potensi peserta didik. Standar proses merupakan salah satu dari 8 standar nasional pendidikan (SNP) sebagai kriteria minimal mutu pendidikan. Standar yang lain adalah standar kompetensi lulusan, isi, standar kompetensi lulusan; standar pendidik dan tenaga kependidikan; standar sarana dan prasarana; standar pengelolaan; standar pembiayaan; dan standar penilaian pendidikan (PP 19 Tahun 2005 dan PP Nomor 32 Tahun 2013). Standar proses mencakup perencanaan proses pembelajaran, pelaksanaan, penilaian, dan pengawasan proses pembelajaran.

Manajemen sarana dan prasarana adalah suatu kegiatan yang mengatur mempersiapak segala peralanan bagi terselangaranya pendidikan (Dawos, Suharto, \& Rosalin, 2013) Dalam manajemen pendidikan terdapat sub-bagian yang membahasa mengenai manajemen sarana prasarana,dalam manajemen saran prasaran terdapat beberapa bagian yang harus diterapkan agar sekolah mengatur bagaimana sekolah dapat melaksanakn proses manajerial sarana dan prasara di sekolah,diantara langkah-langkah manajemen sarana prasarana tersebut ialah perencanaan,pengorganisasian, pengadaan, inventarisasi,penyimpanan,pemiliharaan, dan penghapusan. Agar terpenuhi tujuan manajemen sarana prasaran itu terpenuhi tentunya membuhkan beberpa prinsip-prinsip yang harus diperhatikan dalam pengelolaan sarana dan prasarana disekolah.Bafadal mengemkanakan terdapat beberap prinsip manajemen sarana dan prasaranyaitu:

1. Prinsip pencapaian tujuan, prinsip ini bermaksud bahwa sarana prasarana pada lembaga pendidikan selalu harus dalam kondisi siap pakai, serta akan didayagunakan oleh warga sekolah dalam rangka pencapaian tujuan proses belajar mengajar;

2. Prinsip efisiensi, hal ini bermaksud sarana dan prasarana di lembaga pendidikan sekolah dilakukan melalui perencanaan yang tepat, hingga pengadaaan sarana dan prasarana pendidikan yang baik dengan biaya yang lebih murah, serta pemakaianya pun harus dengan seksama hingga mengurangi biaya yang tidak dibutuhkan;

3. Prinsip administrasi, prinsip ini bermaksud sekolah dalam mengelola sarana dan parasana harus selalu patuh terhadap undang-undang nasional, paraturan menteri atau pemerintah, instruksi dari jajaran sekolah yang berhak hingga pada petunjukyang berwewenang secara teknis Prinsip kejelasan tanggung jawab, artina sarana dan prasarana pendidikan di sekolah harus dideligasikan kepada personel sekolah yang mampu bertanggung jawab; 
4. Prinsip kekorenhensif, prinsip ini bermaksuk sekolah sebagai lembaga pendidikan harus mengelola sarana dan prasarana yang ada dengan kerja tim.

Pemanfaatan sarana dan prasara sekolah merupakan salah satu indikator sebagai ukuran tingkat baik atau buruknya layanan yang diberikan sekolah kepada pelanggan. Pemanfaatan sarana prasarana yang baik adalah penggunaan yang disesuaikan dengan kebutuhan, terdapat empat tujuan penggunaan sarana prasarana yang efektif yaitu:

1. tercapainya tujuan

2. relevan penggunaan antarmedia dan pembahasan materi

3. sarana prasarana yang tersedia

4. karakteristik siswa

Penggunaan yang tepat pada sarana dan prasarana merupakan bentuk penunjang dan dukungan tercapainya proses pembelajaran dan pendidikan di sekolah, hingga harapan untuk menjadi sebuah sekolah yang baik dan terus melakukan perbaikan dapat memenuhi kebutuhan dan keinginan dari pelangannya, baik internal mau pun eksternal.Bila sebuah lembaga pendidikan atau sekolah telah mampu memenuhi kebutuhan dan harapan pelangnya maka sekolah tersebut dapat dikatakan sekolah yang memiliki layan mutu yang baik, namun apabila kenyataan dan harapan dari pelangan tidak terpenuhi maka sekolah tersebut dapat dikatakan sekolah yang memberikan layan mutu yang buruk.

\section{KESIMPULAN}

Manajemen sarana dan prasarana adalah suatu kegiatan yang mengatur mempersiapan segala peralatan bagi terselangaranya pendidikan untuk mencapai tujuan pendidikan secara efektif dan efisien. Untuk meningkatkan mutu pendidikan dimasa yang akan datang maka perlu dilakukannya peningkatan kualitas pada administrasi sarana dan prasarana. Prinsip dari manajemen sarana dan prasaranyaitu: Prinsip pencapaian tujuan, Prinsip efisiensi, Prinsip administrasi dan Prinsip kekorenhensif.

\section{SARAN}

Berdasarkan pada pembahasan dan kesimpulan yang sudah dipaparkan diatas maka terdapat saran yang dapat disampaikan yaitu sekolah dikatakan sebagai sekolah yang bagus bukan hanya sekolah yang memiliki sarana dan prasarana yang lengkap tetapi juga juga perlu adanya manajemen sarana dan prasarana yang menunjang agar layanan mutu pada sekolah tersebut berjalan dengan baik. Oleh karena iu maka perlu adanya perhatian dari petugas baik itu kepala sekolah atau para staf lainnya untuk memanajemen sarana dan prasaraa disekolah agar dapat dimanfaatkan sebaik mungkin.. 


\section{Daftar Pustaka}

Ismanto, B. (2016). Peningkatan Mutu Pembelajaran Melalui Supervisi Akademik Berdasarkan Mutu Standar Proses Pembelajaran ( Studi Kasus Pemetaan Mutu Pendidikan di Provinsi Jawa Tengah ).

Meningkatkan, D., \& Layanan, M. (2018). Efektivitas pemanfaatan sarana dan prasarana dalam meningkatkan mutu layanan. 2.

Sabandi, A. (2013). Supervisi Pendidikan Untuk Pengembangan Profesionalitas Guru Berkelanjutan. Jurnal Ilmiah Ilmu Pendidikan, XIII(2), 1-9. 